\title{
Blood Platelets and Systemic Sclerosis
}

\author{
Sébastien Lepreux ${ }^{1}$, Anne Solanilla ${ }^{1}$, Julien Villeneuve ${ }^{2}$, \\ Joël Constans ${ }^{3}$, Alexis Desmoulière ${ }^{4}$ and Jean Ripoche ${ }^{1}$ \\ IINSERM U 1026 and Université de Bordeaux, Bordeaux \\ ${ }^{2} C R G$, Barcelona \\ ${ }^{3}$ Service de Médecine Vasculaire, \\ Bordeaux University Hospital, Bordeaux \\ ${ }^{4}$ Department of Physiology and EA 3842, \\ Faculty of Pharmacy, University of Limoges, Limoges \\ 1,3,4France \\ ${ }^{2}$ Spain
}

\section{Introduction}

Systemic sclerosis (SSc) is characterized by a progressive fibrosis of the perivascular and interstitial connective tissues which can involve the skin, heart, lungs, kidneys, and the gastrointestinal tract. SSc is an uncommon, debilitating condition, associated to a vital risk linked to visceral extensions and has a high case-fatality rate among connectivitis. SSc begins in the vast majority of cases with a Raynaud's phenomenon, may have a limited or diffuse skin extension, and is often associated to arterial occlusions, digital ulcerations or necrosis. SSc clinical manifestations are heterogeneous and classifications distinguish limited to diffuse disease, depending on the distribution of the skin lesions and organ involvement [1-3]. There is today no curative treatment. Disease susceptibility differs according to sex, age and race, there is a notable familial clustering, and SSc incidence may be rising $[4,5]$. The clinical management of the patients still remains a difficult challenge and the pharmacopeia offers limited choices to the clinician to bring relief to patients. Pulmonary, renal and myocardial complications have benefited from the introduction of angiotensin converting enzyme inhibitors, calcium pump inhibitors, prostacyclin analogs and endothelin antagonists. Based on recent pathophysiological insights, a number of novel agents are being developed [6-8].

\section{SSc pathogenesis in 2011: An elusive mechanism}

SSc pathogenesis remains obscure. Central features are an inflammatory vasculopathy, perivascular and interstitial sclerosis, altered angiogenesis and autoimmunity. Pathologic changes depend on whether they are observed at an early or late disease stage. The progression of the disease is typified by the accumulation of extra-cellular matrix (ECM) components in connective tissues. There are clinical and pathologic arguments to support the hypothesis that the vasculature is involved at an early step during disease progression. 
Indeed, endothelium damage, perivascular edema and mononuclear cell infiltration are among earliest pathological changes that may precede the development of fibrosis [9-11]. Deregulated vascular tone, as evidenced by the Raynaud's phenomenon and morphological abnormalities of nail-fold capillary loops, as evidenced by capillaroscopy, also witness the underlying vasculopathy. In such a hypothetical vascular perspective, endothelial cell (EC) injury fuels other manifestations of the disease by the way of a deregulated inflammatory reaction. Whatever the primary target, a putative sequence of events leading to progression of the disease may follows microvascular injury leading in turn to perivascular and interstitial inflammation, autoimmunity leading to further endothelium injury, chronic progression of the inflammatory reaction, activation of interstitial fibroblasts, pericytes and other fibrocompetent cells leading to myofibroblast generation and subsequent persistent fibrogenic response $[6,12-18]$. There are arguments to incriminate the genetic background in the disease susceptibility and progression. Genetic studies have underlined the inherent complexity of the disease, highlighting the involvement of the vasculature, the immune system and the ECM. Several polymorphisms in potential candidate genes have been identified [19-24]. The number of genes involved further underlines the disease spectrum heterogeneity. Environmental factors are linked to the disease, this being the case for exposure to silica, organic solvents or vinyl chloride. Infectious agents have been proposed to be involved, through endothelium damage, molecular mimicry-mediated autoimmune responses or other mechanisms $[25,26]$. But how exposure to environmental risk factors combined to a permissive genetic background translates into initiation and progression of the disease is unclear. Therefore, fundamental questions remain currently unanswered with regard to key SSc features such as vascular, autoimmune and fibrotic events. The nature of the EC injury remains unknown. Several potential mechanisms have been explored, such as EC-specific $\mathrm{T}$ cells or auto-antibodies, vasculotropic viruses or environmental factors, oxidative stress, profibrotic and/or inflammatory cytokines. Altered angiogenesis is also a characteristic feature of SSc. Prevalent alterations of the capillary network in SSc include chaotic malformations with giant and bushy capillaries and reduced capillary density. There is, however, an insufficient angiogenic response, a defective vasculogenesis and a capillary loss in SSc [27]. Recent progresses have allowed progressive uncovering of the molecular mechanisms of tissue fibrosis. However, the widespread accumulation of ECM in SSc remain largely misunderstood, and therapeutic attempts to control fibrosis unfortunately remained unsuccessful [17, 18, 28-30].

\section{SSc: A role for platelets?}

A recent expansion of knowledge from basic research has illuminated the role of platelets in the inflammatory signalization network and underlined a hitherto unsuspected role for platelets in inflammatory diseases. Moreover, platelets are linked to endothelium homeostasis. They have been implicated in several vascular and fibrotic disorders. Hence, platelets stand as foreseeable contributors to SSc natural history. Indeed, there are signs of ongoing platelet activation in SSc but the underlying mechanisms remain ill-defined. First, it is not known how platelets could be activated during the course of the disease, through endothelium injury, immunological mechanisms or other reasons; second, it is not clear which platelet-derived mediators may specifically influence the progression of the disease. In the following sections are summarized some of the mechanisms linking platelets with inflammation, angiogenesis, vascular tone and fibrosis. 


\section{Platelets: Central actors of inflammation}

\subsection{Platelets transport bioactive mediators in the bloodstream}

Platelets are cytoplasmic fragments that derive from the fragmentation of megakaryocytes (MKs) in the bone marrow sinuses. They harbor a unique store of secretory organelles having a distinct content in bioactive peptides. Alpha granules contain both soluble proteins destined to be secreted and membrane-bound proteins [31, 32]. Dense granules mostly contain an adenine nucleotide pool of ATP and ADP, bivalent cations calcium and magnesium and amines, including serotonin and histamine [33]. Platelet lysosomes contain a complex set of enzymes including acid proteases, such as cathepsin, carboxypeptidases, collagenases and various glycohydrolases [34]. Following platelet activation, the organelle content is released in a process termed secretion. The bulk of proteins secreted by platelets are remarkably large and diverse, as shown by proteomic studies on either platelet releasates or isolated granules. Classifications of the platelet secretome content with reference to biological effects pinpoint relations that platelets may encompass in various biological functions, including inflammation, tissue repair and angiogenesis [34-37]. Such a complexity has opened many new challenges with reference to the platelet role in human diseases.

In addition to MK biosynthesis, platelets also carry mediators that are endocytosed from plasma and possibly concentrated and/or modified within platelets. Such a plasma uptake has, for example, been demonstrated for fibrinogen, albumin, immunoglobulins, amino acids, and several inflammatory mediators including vascular endothelial growth factor (VEGF), histamine or serotonin [38, 39]. Passive and/or active mechanisms are responsible for the platelet uptake of plasma material. Platelets may be considered as mobile nodes, gathering (through endocytosis) and imparting information to target cells [40]. Apart from the rapid mobilization and release of granule content, platelets also express biomediators, including IL-1 $\beta$, tissue factor, fibrinogen, thrombospondin, von Willebrand factor (vWF), GPIIb and GPIIIa, through a time-, translational-dependent pathway that is triggered upon platelet activation [41-45]. Finally, the traditional concept of platelet loss of function following activation is debated, as activated platelets circulate or persist in clots while keeping functional properties.

\subsection{Platelet-derived microparticles recapitulate essential platelet functions}

Activated platelets shed microparticles (MPs). Platelets are the major source of circulating MPs. MP biological roles recapitulate essential platelet functions as MPs represent a transport and delivery system of mediators participating to hemostasis, thrombosis, vascular repair and inflammation, acting both locally and systemically. MPs may transfer information to EC through adhesion and/or fusion, an event thought to contribute to the control of EC phenotype in inflammation [46-48].

\subsection{Platelet-endothelium: A friend and foe relationship 4.3.1 Platelets maintain vascular integrity}

One of the primary roles of platelets is to maintain vascular integrity [49]. At sites of vascular damage, platelets promptly adhere to exposed ECM [50], but also to activated EC (below), a first step in a sequence of events that result in platelet activation, initiation and propagation of hemostasis and thrombosis and in the release of key material contributing to wound repair and tissue regeneration, including ECM components and ECM remodeling proteins, matrix metalloproteinases (MMPs) and their inhibitors, the tissue inhibitors of 
metalloproteinases (TIMPs). Platelets also provide essential material for the angiogenic process, as summarized below. The role of platelets in tissue repair goes beyond vascular integrity. Indeed, platelets are essential for organ repair and regeneration as remarkably exemplified in the liver [37, 51-53].

\subsubsection{The platelet/endothelium dialogue in inflammation}

The dialogue between platelets and EC is a representative paradigm that has been extensively studied and reviewed because of its relevance in atherosclerosis [54]. PlateletECs interactions are critical in the initiation and progression of vascular inflammation. Platelet-derived inflammatory mediators turn EC phenotype to proinflammatory and procoagulant, and platelets facilitate leukocyte recruitment through the endothelium by providing chemotactic signals and platelet-bound ligands [49, 54]. Platelets are brought to inflammatory sites through vascular leakage, attachment to leukocytes but they also respond to chemotactic signals [55]. Coagulation and inflammation are intricately linked, and platelets represent an integrating platform for coagulation and inflammation cascades. For example, they anchor the procoagulant complex leading to the generation of thrombin a potent proinflammatory mediator. Platelets also contribute to other inflammatory cascades; for example, they propagate complement system activation [56]. Further readings may be found in [49, 54, 57-59].

The inflammatory reaction leads to platelet activation. ECM components, chemokines, triggering of platelet receptors with ligands on inflammatory cells activate platelets. Importantly, activated ECs bind and activate platelets, and the underlying mechanisms have been recently précised [50]. In resting conditions, the endothelium is not adhesive for platelets and prevents platelet activation through multiple mechanisms [60]. Activated ECs support platelet adhesion and activation. Endothelium denudation, resulting in ECM exposure, is not a prerequisite for platelet activation. Indeed, platelets roll and adhere on activated ECs, as shown, for example, after stimulation with Tumor Necrosis Factor- $\alpha$, or following ischemia/reperfusion injury [61, 62]. EC activation (which can occurs through multiple mechanisms, inflammatory mediators, hypoxia, complement activation products, infectious agents...) results in the upregulation of adhesion molecules, including E- and Pselectin, $\alpha_{\mathrm{v}} \beta_{3}$, intercellular adhesion molecule (ICAM)-1 or vWF, all ligands that mediate platelet rolling and firm adhesion in a process presenting profound analogies with the multistep-adhesion mechanisms of leukocytes on ECs [50, 54, 63-68]. Throughout the adhesion process platelets become activated. Activated platelets are a rich source of inflammatory mediators. They secrete a host of cytokines, chemokines, and lipid inflammatory mediators, deliver free acid arachidonic to bystander polymorphonuclear cells, allowing them to generate leukotriens. Activated platelets therefore contribute to generate a complex inflammatory milieu in their vicinity [37, 69, 70]. Platelet-derived inflammatory mediators deliver in turn activating signals to target cells including EC and leukocytes, resulting in the amplification of inflammation.

\subsection{Platelets are a source of angiogenesis mediators}

An important mechanism through which platelets control wound healing is linked to angiogenesis, as exemplified in tumor angiogenesis [71]. Platelets and platelet-derived MPs provide critical material for the generation and stabilization of the neo-angiogenic vessels; they secrete positive regulators and inhibitors of angiogenesis, including chemokines [72- 
78]. Platelets also link coagulation to angiogenesis, through the proteolytic release of several cryptic angiogenic regulators [79]. VEGF is a critical angiogenic mediator in SSc (below) and its connections with platelets have been extensively studied. VEGF is transported by platelets [80]. Following binding to its receptor, VEGF induces EC survival, growth, permeability and migration. Other key angiogenic regulators secreted by platelets are platelet-derived growth factor (PDGF), transforming growth factor, (TGF)- $\beta$ and angiopoietins. The angiogenic response is dependent on a complex regulated balance between the generation of pro- and anti-angiogenic molecules, with reference to magnitude and temporal production sequence [81]. The angiogenic activity of VEGF can only be appreciated by integrating the action of other mediators present in the EC environment [82, 83]. PDGF, TGF- $\beta$ and angiopoietins are such mediators, acting in concert with VEGF for the stabilization of the vascular wall; their imbalanced expression has indeed been implicated in aberrant angiogenesis $[82,84]$. Interestingly, there is a regulated differential secretion of proand anti-angiogenic mediators by platelets with reference to the nature of the agonist [85].

\subsection{Platelet-derived mediators participate to vascular tone regulation}

The blood flow is dependent on the constriction/dilation of resistance arteries. Endothelium and periarterial autonomic nervous plexus provide essential controls of the vascular tone $[86,87]$. ECs are a source of vasoactive mediators that regulate blood flow, including the relaxing factors nitric oxid (NO), prostacyclin (PGI2) or endothelium-derived hyperpolarizing factor and vasoconstrictive factors including thromboxane A2 or endothelin-1 [88, 89]. Recent progress has highlighted the involvement of platelets and platelet-derived MPs in the control of the vascular tone. The integrity of the endothelium appears central to the vasomotor response to platelets; on intact endothelium, platelet derived mediators, including serotonin and ADP, cause the release of relaxing factors by the endothelium. If endothelium dysfunction has occurred, the absence of its protective role allows platelet-derived mediators, including serotonin and thromboxan A2 to induce vasoconstriction by directly acting on smooth muscle cells [90, 91]. Interestingly, VEGF may prove to have an increasing importance in vascular flow regulation, apart from its role in angiogenesis. Recent evidences indicate that it preserves the structure and function of neuro-effectors junctions [87].

\subsection{Platelets are a source of fibrogenic mediators}

Platelets are a rich source of pro-fibrotic molecules. Tissue fibrosis results from a deregulated wound-healing response to chronic injury. It is typically associated to a perpetuating inflammatory response, resulting for example from the persistence or repeated release of a tissue irritant, in contrast to the regulated acute inflammatory response that ends in a resolution step, repair of tissue damage and tissue homeostasis [92]. A central feature of tissue fibrosis is a quantitatively and qualitatively altered production of ECM. The increased biosynthesis of ECM components, particularly fibrillar collagens, by fibrocompetent cells contributes to generate a permanent and destructive tissue scarring that impairs organ function. Fibrocompetent cell activation is therefore at the root of the natural history of tissue fibrosis, and one of its decisive manifestations is transdifferentiation towards myofibroblasts, expressing $\alpha$-smooth muscle actin (SMA), and harboring characteristic stress fibers and contractile phenotype [93]. It is generally accepted that the major source of myofibroblasts are local connective tissue fibroblasts. However, they can also be recruited 
from circulating fibrocytes and bone marrow-derived mesenchymal precursors, or they can derive from local epithelial and endothelial cells through the epithelial-mesenchymal transition [94-99]. Multiple soluble signals activate fibrocompetent cells. Among the most studied in SSc are the growth factors TGF- $\beta 1$, PDGF, endothelin- 1 and connective tissue growth factor. These mediators are potent fibroblast activators. TGF- $\beta 1$ holds a peculiar position in SSc, as its deregulated expression represents a critical step. TGF- $\beta 1$ promotes myofibroblastic transdifferentiation of quiescent fibroblasts, clearly demonstrated by the induction of $\alpha$-SMA [100], stimulates their proliferation and the synthesis of ECM components, including fibrillar collagens. Epithelial-mesenchymal transition is linked to inflammation and fibrosis and several pro-fibrotic mediators induce the epithelialmesenchymal transition [101]. A hierarchical induction of pro-fibrotic mediators in tissue fibrosis has been emphasized [102]. Chemokines, as monocyte chemotactic protein MCP1, RANTES (regulated upon activation, normal T-cell expressed and secreted), interleukin (IL)-8, activate fibrogenic cells, including skin fibroblasts, stimulating their proliferation, chemotaxis, and ECM biosynthesis. The interaction between keratinocytes and fibroblasts is a critical step during the early phase of wound healing in the skin. Fibroblasts produce keratinocyte growth factor and, conversely, keratinocytes signal to fibroblasts leading to their activation, production of a variety of cytokines/chemokines/angiogenic mediators, induction of ECM component synthesis and $\alpha$-SMA expression [102, 103]. There are important connections between vascular remodeling, angiogenesis and tissue fibrosis. Deregulated vascular remodeling is an important parameter in promoting the development of fibrosis and an imbalance between the production of angiogenic and antiangiogenic factors, such as CXC chemokines, at sites of tissue injury, is relevant to tissue fibrosis [17, 104-106]. Finally, a regulated balance between ECM production and degradation is a sine qua non condition for harmonious wound repair and tissue regeneration. Indeed, as shown in humans and in experimental tissue fibrosis models, the increased expression of some of TIMPs, a family of enzymes that control MMP activity through the inhibition of their proteolytic activity and the control of proform cleavage, leads to an altered MMP/TIMP balance, ECM homeostatic degradation/production disequilibrium, and ECM accumulation [107].

Platelets are essential actors in these mechanisms. They transport and secrete most of above -mentioned pro-fibrotic mediators, angiogenic and anti-angiogenic mediators, including CXC chemokines, ECM components and ECM remodeling proteins MMPs and TIMPs [108, 109]. Platelets influence cell growth and differentiation in a variety of situations [110]. They provide key control signals to angiogenesis. Persistent platelet activation in the microvascular bed may therefore contribute to tissue fibrosis [111-113]. However, few studies have considered their potential contribution. In fact, platelet-derived mediators have only recently being acknowledged as being of key importance in fibrosis as observed in liver and pulmonary diseases and, very recently, in SSc (below).

\section{Evidence for platelet activation in SSc}

There are signs of platelet activation in SSc, as indicated by measurements of various soluble and membrane-bound markers, circulating MPs and platelet- and plateletleukocyte aggregates (Table 1). Soluble markers have been largely studied. As there are signs of ongoing EC injury in SSc, the specificity of these markers is an important point. P- 
selectin (CD62p) is a component of $\alpha$-granules and of intracellular EC storage organelles. There has been debate whether the increase in plasma CD62p truly reflects platelet activation, as it is also expressed on activated ECs. It is however currently clear that most, if not all, measured plasma CD62p has a platelet origin [114, 115]. Activated ECs have also been discussed as potential contributors to soluble CD154 (sCD154). In fact, correlation studies demonstrated that it can be considered as mostly derived from platelets [116], but, recently, other cell sources have been described, that may potentially contribute to elevated circulating sCD154 levels [117]. Soluble P-selectin glycoprotein ligand-1 is elevated in SSc [118], which may also reflect some degree of platelet activation as it is expressed by platelets [119]. Chemokine (C-X-C motif) ligand-4 (CXCL4, Platelet Factor 4) is elevated in SSc; albeit until recently described as exclusively derived from platelets, other sources exist such as T-cells or macrophages that may be contributors to elevated circulating levels [120]. Tissue-plasminogen activator (tPA) has also been described as a marker of EC damage [121]. Studies of the expression of platelet membrane-bound activation markers also show that platelets are not globally activated, but that this activation concerns a fraction of their population [122]. Correlation studies in general do not evidence relations with clinical features of the disease, but this is a matter of debate as correlations were found for some markers such as sCD154, thromboxane B2 or MPs (Table 1). Finally, morphological electron microscopy-based studies also suggest platelet enhanced activability in SSc, and there are signs of platelet granule release [111, 123, 124]. A major point is that platelet activation may be prominently linked to the Raynaud's phenomenon. Indeed, features of platelet activation are also found in the primary Raynaud's phenomenon (below).

Platelet activation markers $\begin{aligned} & \text { Correlations with disease } \\
& \text { features }\end{aligned}$
\begin{tabular}{|l|l|l|}
\hline $\begin{array}{l}\text { Circulating platelet } \\
\text { aggregates }\end{array}$ & Not found & {$[125-127]$} \\
\hline Platelet-leucocyte aggregates & Not found [128] & {$[128]$} \\
\hline$\beta-T G$ & Not found [122]; [130] & {$[122] ;[125-127] ;[129-134] ;$} \\
\hline Serotonin & Not found & $\begin{array}{l}{[135] \text { (in the CREST }} \\
\text { variant); [136] (also in } \\
\text { platelets) }\end{array}$ \\
\hline CXCL4 & Not found & $\begin{array}{l}{[126] ;[131] ;[133] ; \text { Radstake }} \\
\text { Arthritis Rheum 2010;62 }\end{array}$ \\
\hline $\begin{array}{l}\text { Suppl 10 :1210 (Abstract); } \\
{[134]}\end{array}$ \\
$\begin{array}{l}\text { or urines (Thromboxane A2 } \\
\text { metabolite) }\end{array}$ & $\begin{array}{l}\text { Positive correlation with } \\
\text { dSSc (Herrick 1996) } \\
{[139]}\end{array}$ & {$[134] ;[137-139] ;$} \\
\hline TSP-1 & Not found & {$[133]$} \\
\hline tPA & & {$[132]$} \\
\hline Membrane CD62P & Not found & {$[122] ;[128]$} \\
\hline Soluble CD62P & Not found & {$[140]$} \\
\hline
\end{tabular}




\begin{tabular}{|l|l|l|}
\multicolumn{1}{|c|}{ Platelet activation markers } & \multicolumn{1}{l|}{$\begin{array}{l}\text { Correlations with disease } \\
\text { features }\end{array}$} & References \\
\hline sCD154 & $\begin{array}{l}\text { Positive correlation with } \\
\text { lSSc, with digital ulcers and } \\
\text { pulmonary arterial } \\
\text { hypertension [141] }\end{array}$ & [141]; [142] \\
\hline Platelet-derived MPs & $\begin{array}{l}\text { Inverse correlation to the } \\
\text { modified Rodnan thickness } \\
\text { score [143] }\end{array}$ & [128]; [143] \\
\hline
\end{tabular}

Table 1. Markers of platelet activation in SSc

Platelet activation in SSc is documented by several studies. Markers have been measured in plasma or serum or on platelets (CD62P). The elevation of circulating tPA is not always found $[139,144]$. Abbreviations: $\beta$-TG, $\beta$-thromboglobulin ; TSP- 1 , thrombospondin- 1 ; dSSc, diffuse cutaneous SSc; 1SSc, limited cutaneous SSc ([2]). Other abbreviations are spelled in the text.

\section{Lack of platelet morphological abnormalities and count in SSc}

There are no specific recognized abnormalities of the platelet count in SSc. Moderate thrombocytosis or thrombocytopenia are occasionally observed, and have been related to inflammation or microangiopathy, respectively $[145,146]$. Platelet morphology is not altered.

\section{Potential mechanisms mediating platelet activation in SSc}

Mechanisms underlying platelet activation in SSc remain ill-defined. Questions that have been pursued are: (i) is there a platelet dysfunction in patients that would reduce the threshold level of platelet response to activating signals? (ii) are platelets activated in SSc as the result of EC injury, autoantibodies directed at platelets or other reasons? (iii) what is the role played by the Raynaud's phenomenon?

\subsection{Is there a platelet disorder in SSc leading to platelet hyperactivability?}

Several studies have examined the eventuality of platelet dysfunction in SSc (Table 2). Reports suggest augmented responsiveness of platelets to their physiological agonists, either strong agonists, such as thrombin or collagen, or weak agonists, such as serotonin, ADP, epinephrine or arachidonic acid, resulting in a reduced threshold of platelet aggregation to the agonist stimulus. Conversely, there is a reduced response to inhibitors of platelet activation such as prostacyclin. However, there are contradictory reports (Table 2). Platelet response to agonists as measured by the hyperactive phenotype is often difficult to interpret. There is a significant variability between individuals, as several genetic modifiers may influence platelet function and as platelet hyperactivity, as measured by aggregometry, can be detected in healthy individuals $[147,148]$. Also, in vivo, platelet activation results from the combinational input of agonists that act in a complex synergistic way and vary from donor to donor [149-152]. The application of neural networks approaches for predicting platelet response to a complex milieu may represent a useful tool for studying platelet activation response to agonists in SSc. There are no straightforward interpretations of changes in platelet function in SSc. Interestingly, binding assays of radiolabelled collagen indicate a specific increase in the expression of the platelet collagen type 1 receptor in SSc patients [153], which would explain the enhanced response to collagen and indicate a 
primary or acquired defect. Proteomic studies on platelet compartments in SSc patients could help finding a potential primary or acquired platelet defects in this disease.

Platelet function changes References

\begin{tabular}{|l|l|}
\hline $\begin{array}{l}\text { Hyperaggregability } \\
\text { Spontaneous (in whole blood) } \\
\text { In response to agonists }\end{array}$ & {$[126] ;[131] ;[154-158]$} \\
\hline Enhanced adhesion to collagen & {$[159] ;$} \\
\hline Reduced sensitivity to PGI2 & {$[160]$} \\
\hline $\begin{array}{l}\text { Increased platelet sensitivity to collagen- } \\
\text { induced aggregation }\end{array}$ & {$[138] ;[157]$} \\
\hline $\begin{array}{l}\text { Increased expression of collagen type } 1 \\
\text { receptor }\end{array}$ & {$[153]$} \\
\hline Hyperaggregability not found & {$[161]$} \\
\hline
\end{tabular}

Table 2. Changes in platelet functions in SSc

\subsection{Potential mechanisms mediating platelet activation in SSc}

Platelet activation in SSc may first be the consequence of endothelium injury. Indeed, the canonical role of platelets is to react to endothelium damage, a circumstance that activates a bidirectional dialogue between ECs and platelets, initiating and sustaining inflammation. Through soluble and platelet-bound signals, activated platelets confer ECs a proinflammatory and procoagulant phenotype and, reciprocally, EC activation, as met in inflammation, leads to platelet activation resulting in a pro-inflammatory amplification loop. The balance of signals that keep platelet from being activated may be overcome in a variety of conditions. As summarized above, not only platelets react to the endothelial barrier loss of integrity with consequent exposure of the underneath collagen-rich matrix, but they also react to slighter features of EC activation, which do not lead per se to severe endothelium damage, as met for example in conditions in which ECs are activated by cytokines including TNF $\alpha$, IL-1, VEGF, by oxidative stress or hypoxia [80, 162-165]. These signals induce the expression of a range of molecules promoting platelet adhesion on ECs. Platelets bind to these docking structures, an event that initiates their activation. These conditions also induce ECs to produce platelet agonists, such as multimeric vWF and ADP. Inflammation and coagulation are inextricably linked. Activated ECs express tissue factor, leading to the activation of coagulation, platelet activation, thrombin generation and further amplification of the inflammatory reaction. This is dramatically exemplified in renal involvement in SSc, characterized by thrombotic microangiopathy lesions. On electron microscopy studies, aggregates of platelets admixed with fibrin and fragmented red blood cells are observed within small interstitial vessels or glomerular capillaries. Hypoxia is a noxious stimulus that activates a range of inflammatory pathways, leading to EC activation through multiple mechanisms, including the production of angiogenic factors [166-168]. Hypoxia is thought to play a critical role in SSc. SSc-associated microangiopathy results in a disturbed blood flow in the capillaries with consequent hypoxia, which is likely to be 
aggravated by tissue fibrosis [169-172]. Hypoxia alters vascular endothelium but also directly activates platelets $[173,174]$ (our unpublished results). Altogether, conditions that turn EC phenotype to proinfammatory/prothrombotic are translated into platelet adhesion and activation, with the consequent release of inflammatory, mitogenic, angiogenic and fibrogenic platelet-derived mediators described above. These mediators further activate ECs, promoting the production of cytokine/chemokines, induction of adhesion and procoagulant molecules, and production and activation of MMPs. Moreover, ECs undergoing apoptosis become proadhesive for platelets [175], and activated platelets can in turn induce EC apoptosis [176].

In fact, endothelial injury in the microcirculation and arterioles is a predominant feature of SSc which has extensively been reviewed [13, 30, 177-180]. There are circulating stigmata of endothelial injury, including von Willebrand factor and supranormal (larger) vWF multimers [126, 131, 139, 181-184], soluble adhesion molecules, such as E-selectin or vascular cell adhesion molecule (VCAM)-1 and ICAM-1, thrombomodulin, tPA, or endothelin [185188]. Increased nitrate in the plasma or serum of patients has been described, and been related to EC injury, as there are correlations with soluble E-selectin and soluble VCAM-1 $[189,190]$. Elevated circulating ECs were also attributed to vascular damage in SSc [191]. EC apoptosis is a common and early feature in SSc [192]; however pathologic evidence for EC apoptosis remains controversial [177]. However there are inherent limitations to the interpretations of such biomarkers [193], these results show that there is an early insult to the vasculature during the course of the disease.

Importantly, the Raynaud's phenomenon itself, one, if not the first manifestation of SSc, preceding the onset of other symptoms of the disease [194-198], is associated with platelet activation [132]. The absence of endothelium abnormalities in the primary Raynaud's phenomenon is generally accepted, although limited morphological abnormalities have been described [199]. However, features of platelet activation are found in primary Raynaud's phenomenon [158, 200, 201] and platelet activation was proposed to play a role in its pathogenesis $[135,202]$. Therefore, events responsible for the Raynaud's phenomenon lead to platelet activation in the absence of EC damage, a possible argument to place platelet activation as a very early pathogenic event in the reciprocal activation dialogue between platelets and ECs. Intriguingly, several factors that have been put forward as being potentially causative or susceptible to modify the progression of SSc, as exposure of extremities to cold, mechanical vibrations, exposure to organic solvents or silica, CMV infection are associated to some extent to platelet activation, and for some of them to trigger the Raynaud's phenomenon.

Finally, autoantibodies against platelet gpIIb/IIIa have been described in SSc [203]. However their role in platelet activation remains uncertain.

\section{Platelet activation and the progression of SSc}

SSc is a complex disease for which no specific causative mechanism has been identified. The disease may be initiated in the vasculature, as morphological changes are apparent before the onset of the disease; however, it is not clear how endothelium injury begins. Platelets play a large and complex physiological role in health and disease, as they contribute to hemostasis, inflammation, tissue repair, and to the innate and adaptative immunity, standing as essential links $[69,204]$. Platelets establish intimate bidirectional relationship 
with the endothelium, making them potential contributors to SSc vasculopathy. The microcirculation is a characteristic target in SSc pathogenesis. Microcirculation hemorheologic conditions result in an intimate platelet/endothelium interface, characterized by a near capillary wall platelet concentration. Clearly, cross-interactions between ECs and platelets are inextricably linked under the form of feed-back activation loops and whether or not being a primary event, any condition leading to an endothelium insult drives platelet activation. Conversely, platelet activation drives to EC activation; the fact that platelet activation is observed in the primary Raynaud's phenomenon, in the absence of EC detectable damage, may signify that subtle early events activating platelets, such as disturbed blood flow or hypoxia, precede the onset of the disease. Following platelet activation in the microcirculation, as described above, a wide array of soluble and plateletbound mediators with a pleiotropic range of actions are released that can contribute to several pathophysiological features of the disease including (i) vascular tone dysregulation, (ii) endothelium activation, (iii) inflammation, (iv) activation of the coagulation system, (v) fibrogenic response, (vi) altered angiogenesis. Apart from the possible deleterious cross-talk between endothelium and platelets, described above, two chief features of SSc progression that may be connected to platelets have been the subject of very recent reports. Altered angiogenesis and progressive perivascular and interstitial fibrosis are hallmarks of SSc [27]. First as summarized above, platelets are essential contributors to angiogenesis during wound healing, and ongoing platelet activation in capillary beds may be involved in the altered angiogenesis associated with SSc. In fact, in line with the major VEGF transporter role of platelets, platelet VEGF is increased in SSc patients. However, this is not the case for other angiogenic regulators, such as TGF- $\beta 1$, PDGF-BB or angiopoietins [122]. VEGF, jointly with other mediators, determines the angiogenic or non-angiogenic status of the EC and an imbalance between the relative concentrations of angiogenic mediators is likely to alter angiogenesis homeostasis [170,177]. Indeed, the deregulated expression of VEGF is thought to lead to abnormal angiogenesis, as exemplified by the resulting disorganization of the capillary network with large, leaky, fragile capillaries; dynamic parameters, such as the magnitude or the kinetics of VEGF release being critically important [170, 205-207]. Therefore platelet activation in the patient's microvascular beds may result in the release of inappropriate combinations of angiogenic and angiostatic mediators, and such disequilibrium may be relevant to the vascular disease in SSc [122, 208, 209]. Further, as summarized above, there are connections between angiogenesis, vascular remodeling and fibrosis and an unbalance between factors promoting and factors inhibiting angiogenesis may also be relevant to the progression of fibrosis. Second, as summarized above, platelets provide a cornucopia of mediators that may be relevant to the natural history of tissue fibrosis, i.e. through fibrocompetent cell activation. Sustained activation of fibrocompetent cells contribute to excessive ECM production in tissues. Indeed, fibroblasts expanded from the fibrotic skin or lungs from SSc patients have a myofibroblastic phenotype and there is a strong correlation between myofibroblast labeling in the lesional skin and the Rodnan skin score [210]. Crucial platelet links with tissue fibrosis have recently been emphasized in humans. In liver fibrosis the secretion of platelet-derived CXCL4 is instrumental [211]. In SSc, the role of platelet-derived serotonin in skin fibrosis is strongly suggested by the stimulation of the production of ECM by serotonin through binding to dermal fibroblasts serotonin receptor $5-\mathrm{HT}_{2 \mathrm{~B}}$, increased expression of $5-\mathrm{HT}_{2 \mathrm{~B}}$ in the fibrotic skin of SSc patients and reduction of experimental fibrosis through pharmacological targeting of the 5-HT/5$\mathrm{HT}_{2 \mathrm{~B}}$ signaling and anti-platelet drugs [212]. 


\section{Conclusion; Platelet activation in SSc: A deleterious loop?}

The primary triggering event in SSc remains unclear. However, inflammation of the vasculature is a common denominator, whether resulting from an autoimmune response to a yet undefined antigen or other mechanisms. Whatever the primary target, inflammation leads to EC activation and, due to the reciprocal activating interplay between platelets and endothelium, EC activation in turn activates platelets and vice-versa. Platelet activation, through the release of cytokines, chemokines, angiogenic and chemotactic mediators...., amplifies the inflammatory reaction by triggering its many facets, including leukocyte recruitment, leading to further endothelium activation and perivascular inflammation, deregulated angiogenesis and, eventually, fibrosis (Figure 1). A chronic inflammatory scenario may contribute to fibrosis by the way of fibrocompetent cell activation, if the initial pathogenic trigger persists, either continuously or repetitively. Self-sustained myofibroblastdependent fibrotic process takes place on the grounds of a chronic inflammation. Platelets may therefore stand at an important place in the ill-understood hierarchy of cell and soluble mediators interplay responsible for the disease. This scenario is evidently highly simplified due to the extreme complexity and heterogeneity of the disease pathophysiology. The lack of suitable animal models [213, 214] that would accurately recapitulate each steps of SSc progression remains a real handicap to understand the natural history of this disease.

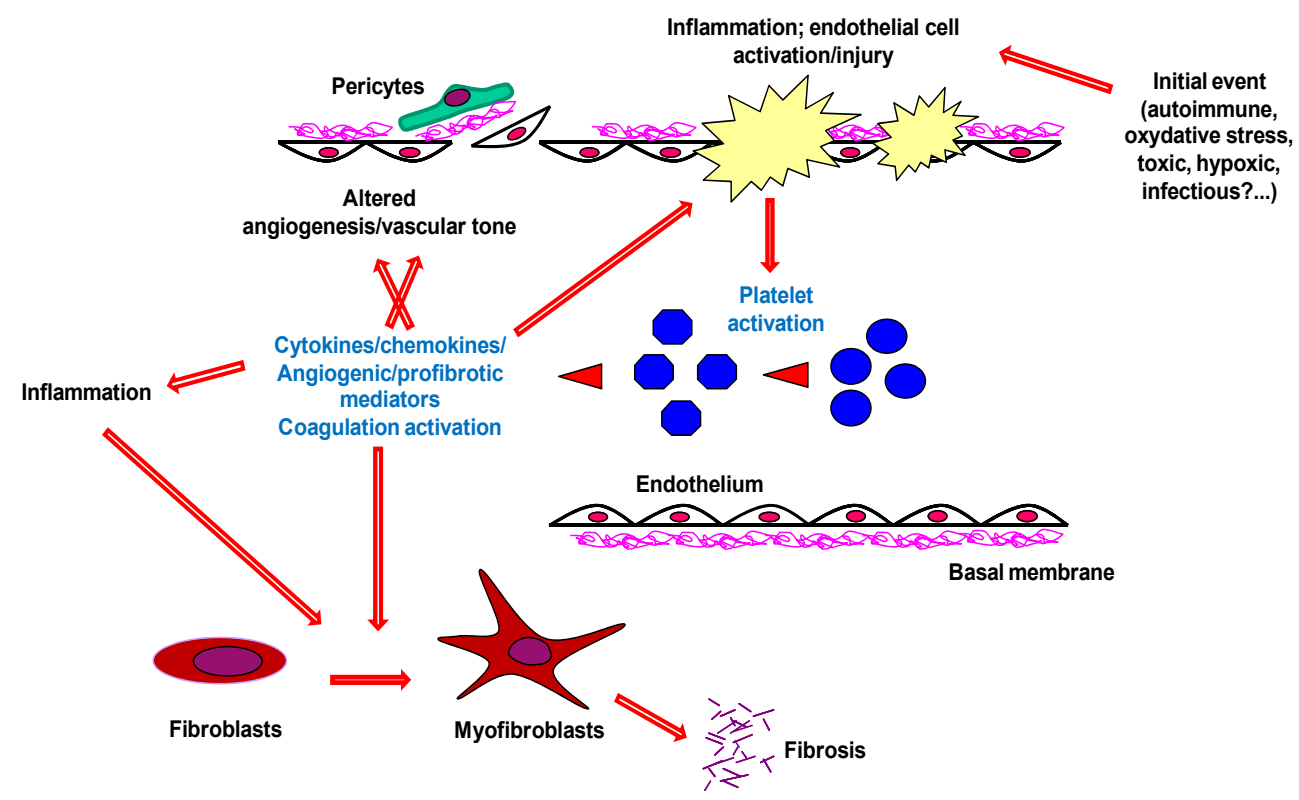

Fig. 1. Platelet activation in SSc: a deleterious loop?

This schematic model underlines the potential role that platelets may play in the initiation and progression of SSc; see text for details. The role of platelet-derived MPs may also be an important point to consider, as they recapitulate several platelet functions and may transfer platelet deleterious effects at sites distant from their generation. 


\section{Acknowledgments}

Work supported by the Groupe Français de Recherche sur la Sclérodermie and the Association des Sclérodermiques de France. Julien Villeneuve is supported by an EMBO long term fellowship.

\section{References}

[1] Preliminary criteria for the classification of systemic sclerosis (scleroderma). Subcommittee for scleroderma criteria of the American Rheumatism Association Diagnostic and Therapeutic Criteria Committee. Arthritis Rheum. 1980;23:581-90.

[2] LeRoy EC, Black C, Fleischmajer R, Jablonska S, Krieg T, Medsger TA, Jr., et al. Scleroderma (systemic sclerosis): classification, subsets and pathogenesis. J Rheumatol. 1988;15:202-5.

[3] Matucci-Cerinic M, Steen V, Nash P, Hachulla E. The complexity of managing systemic sclerosis: screening and diagnosis. Rheumatology (Oxford). 2009;48 Suppl 3:iii8-13.

[4] Mayes MD, Lacey JV, Jr., Beebe-Dimmer J, Gillespie BW, Cooper B, Laing TJ, et al. Prevalence, incidence, survival, and disease characteristics of systemic sclerosis in a large US population. Arthritis Rheum. 2003;48:2246-55.

[5] Chifflot H, Fautrel B, Sordet C, Chatelus E, Sibilia J. Incidence and prevalence of systemic sclerosis: a systematic literature review. Semin Arthritis Rheum. 2008;37:223-35.

[6] Gabrielli A, Avvedimento EV, Krieg T. Scleroderma. N Engl J Med. 2009;360:1989-2003.

[7] Kowal-Bielecka O, Landewe R, Avouac J, Chwiesko S, Miniati I, Czirjak L, et al. EULAR recommendations for the treatment of systemic sclerosis: a report from the EULAR Scleroderma Trials and Research group (EUSTAR). Ann Rheum Dis. 2009;68:620-8.

[8] Quillinan NP, Denton CP. Disease-modifying treatment in systemic sclerosis: current status. Curr Opin Rheumatol. 2009;21:636-41.

[9] Freemont AJ, Hoyland J, Fielding P, Hodson N, Jayson MI. Studies of the microvascular endothelium in uninvolved skin of patients with systemic sclerosis: direct evidence for a generalized microangiopathy. Br J Dermatol. 1992;126:561-8.

[10] Prescott RJ, Freemont AJ, Jones CJ, Hoyland J, Fielding P. Sequential dermal microvascular and perivascular changes in the development of scleroderma. J Pathol. 1992;166:255-63.

[11] Trotta F, Biagini G, Cenacchi G, Ballardini G, Varotti C, Passarini B, et al. Microvascular changes in progressive systemic sclerosis: immunohistochemical and ultrastructural study. Clin Exp Rheumatol. 1984;2:209-15.

[12] Chizzolini C. Update on pathophysiology of scleroderma with special reference to immunoinflammatory events. Ann Med. 2007;39:42-53.

[13] Kahaleh B. Vascular disease in scleroderma: mechanisms of vascular injury. Rheum Dis Clin North Am. 2008;34:57-71; vi.

[14] Kahaleh MB, Sherer GK, LeRoy EC. Endothelial injury in scleroderma. J Exp Med. 1979;149:1326-35.

[15] Katsumoto TR, Whitfield ML, Connolly MK. The pathogenesis of systemic sclerosis. Annu Rev Pathol.2011;6:509-37.

[16] Varga J. Systemic sclerosis: an update. Bull NYU Hosp Jt Dis. 2008;66:198-202. 
[17] Varga J, Abraham D. Systemic sclerosis: a prototypic multisystem fibrotic disorder. J Clin Invest. 2007;117:557-67.

[18] Varga JA, Trojanowska M. Fibrosis in systemic sclerosis. Rheum Dis Clin North Am. 2008;34:115-43; vii.

[19] Agarwal SK, Reveille JD. The genetics of scleroderma (systemic sclerosis). Curr Opin Rheumatol.2010;22:133-8.

[20] Radstake TR, Gorlova O, Rueda B, Martin JE, Alizadeh BZ, Palomino-Morales R, et al. Genome-wide association study of systemic sclerosis identifies CD247 as a new susceptibility locus. Nat Genet.2010;42:426-9.

[21] Whitfield ML, Finlay DR, Murray JI, Troyanskaya OG, Chi JT, Pergamenschikov A, et al. Systemic and cell type-specific gene expression patterns in scleroderma skin. Proc Natl Acad Sci U S A. 2003;100:12319-24.

[22] Gardner H, Shearstone JR, Bandaru R, Crowell T, Lynes M, Trojanowska M, et al. Gene profiling of scleroderma skin reveals robust signatures of disease that are imperfectly reflected in the transcript profiles of explanted fibroblasts. Arthritis Rheum. 2006;54:1961-73.

[23] Agarwal SK, Tan FK, Arnett FC. Genetics and genomic studies in scleroderma (systemic sclerosis). Rheum Dis Clin North Am. 2008;34:17-40; v.

[24] Milano A, Pendergrass SA, Sargent JL, George LK, McCalmont TH, Connolly MK, et al. Molecular subsets in the gene expression signatures of scleroderma skin. PLoS One. 2008;3:e2696.

[25] Hamamdzic D, Kasman LM, LeRoy EC. The role of infectious agents in the pathogenesis of systemic sclerosis. Curr Opin Rheumatol. 2002;14:694-8.

[26] Randone SB, Guiducci S, Cerinic MM. Systemic sclerosis and infections. Autoimmun Rev. 2008;8:36-40.

[27] Manetti M, Guiducci S, Ibba-Manneschi L, Matucci-Cerinic M. Mechanisms in the loss of capillaries in systemic sclerosis: angiogenesis versus vasculogenesis. J Cell Mol Med.2010;14:1241-54.

[28] Abraham DJ, Varga J. Scleroderma: from cell and molecular mechanisms to disease models. Trends Immunol. 2005;26:587-95.

[29] Gilliam AC. Scleroderma. Curr Dir Autoimmun. 2008;10:258-79.

[30] Abraham DJ, Krieg T, Distler J, Distler O. Overview of pathogenesis of systemic sclerosis. Rheumatology (Oxford). 2009;48 Suppl 3:iii3-7.

[31] Blair P, Flaumenhaft R. Platelet alpha-granules: basic biology and clinical correlates. Blood Rev. 2009;23:177-89.

[32] Harrison P, Cramer EM. Platelet alpha-granules. Blood Rev. 1993;7:52-62.

[33] McNicol A, Israels SJ. Platelet dense granules: structure, function and implications for haemostasis. Thromb Res. 1999;95:1-18.

[34] Rendu F, Brohard-Bohn B. The platelet release reaction: granules' constituents, secretion and functions. Platelets. 2001;12:261-73.

[35] Gnatenko DV, Perrotta PL, Bahou WF. Proteomic approaches to dissect platelet function: Half the story. Blood. 2006;108:3983-91.

[36] Maguire PB. Platelet proteomics: identification of potential therapeutic targets. Pathophysiol Haemost Thromb. 2003;33:481-6.

[37] Nurden AT, Nurden P, Sanchez M, Andia I, Anitua E. Platelets and wound healing. Front Biosci. 2008;13:3532-48. 
[38] Handagama P, Rappolee DA, Werb Z, Levin J, Bainton DF. Platelet alpha-granule fibrinogen, albumin, and immunoglobulin $\mathrm{G}$ are not synthesized by rat and mouse megakaryocytes. J Clin Invest. 1990;86:1364-8.

[39] Mercado CP, Kilic F. Molecular mechanisms of SERT in platelets: regulation of plasma serotonin levels. Mol Interv. 2010;10:231-41.

[40] Warkentin TE, Aird WC, Rand JH. Platelet-endothelial interactions: sepsis, HIT, and antiphospholipid syndrome. Hematology Am Soc Hematol Educ Program. 2003:497-519.

[41] Booyse F, Rafelson ME, Jr. In vitro incorporation of amino-acids into the contractile protein of human blood platelets. Nature. 1967;215:283-4.

[42] Kieffer N, Guichard J, Farcet JP, Vainchenker W, Breton-Gorius J. Biosynthesis of major platelet proteins in human blood platelets. Eur J Biochem. 1987;164:189-95.

[43] Warshaw AL, Laster L, Shulman NR. Protein synthesis by human platelets. J Biol Chem. 1967;242:2094-7.

[44] Weyrich AS, Dixon DA, Pabla R, Elstad MR, McIntyre TM, Prescott SM, et al. Signaldependent translation of a regulatory protein, Bcl-3, in activated human platelets. Proc Natl Acad Sci U S A. 1998;95:5556-61.

[45] Weyrich AS, Lindemann S, Tolley ND, Kraiss LW, Dixon DA, Mahoney TM, et al. Change in protein phenotype without a nucleus: translational control in platelets. Semin Thromb Hemost. 2004;30:491-8.

[46] Flaumenhaft R. Formation and fate of platelet microparticles. Blood Cells Mol Dis. 2006;36:182-7.

[47] Italiano JE, Jr., Mairuhu AT, Flaumenhaft R. Clinical relevance of microparticles from platelets and megakaryocytes. Curr Opin Hematol. 2010;17:578-84.

[48] Mause SF, Weber C. Microparticles: protagonists of a novel communication network for intercellular information exchange. Circ Res. 2010;107:1047-57.

[49] Smyth SS, McEver RP, Weyrich AS, Morrell CN, Hoffman MR, Arepally GM, et al. Platelet functions beyond hemostasis. J Thromb Haemost. 2009;7:1759-66.

[50] Gawaz M. Role of platelets in coronary thrombosis and reperfusion of ischemic myocardium. Cardiovasc Res. 2004;61:498-511.

[51] Lesurtel M, Graf R, Aleil B, Walther DJ, Tian Y, Jochum W, et al. Platelet-derived serotonin mediates liver regeneration. Science. 2006;312:104-7.

[52] Nocito A, Georgiev P, Dahm F, Jochum W, Bader M, Graf R, et al. Platelets and platelet-derived serotonin promote tissue repair after normothermic hepatic ischemia in mice. Hepatology. 2007;45:369-76.

[53] Stellos K, Kopf S, Paul A, Marquardt JU, Gawaz M, Huard J, et al. Platelets in regeneration. Semin Thromb Hemost. 2010;36:175-84.

[54] Gawaz M, Langer H, May AE. Platelets in inflammation and atherogenesis. J Clin Invest. 2005;115:3378-84.

[55] Czapiga M, Gao JL, Kirk A, Lekstrom-Himes J. Human platelets exhibit chemotaxis using functional N-formyl peptide receptors. Exp Hematol. 2005;33:73-84.

[56] Del Conde I, Cruz MA, Zhang H, Lopez JA, Afshar-Kharghan V. Platelet activation leads to activation and propagation of the complement system. J Exp Med. 2005;201:871-9.

[57] May AE, Seizer P, Gawaz M. Platelets: inflammatory firebugs of vascular walls. Arterioscler Thromb Vasc Biol. 2008;28:s5-10. 
[58] Weber C. Platelets and chemokines in atherosclerosis: partners in crime. Circ Res. 2005;96:612-6.

[59] Weyrich AS, Zimmerman GA. Platelets: signaling cells in the immune continuum. Trends Immunol. 2004;25:489-95.

[60] Pober JS, Sessa WC. Evolving functions of endothelial cells in inflammation. Nat Rev Immunol. 2007;7:803-15.

[61] Frenette PS, Johnson RC, Hynes RO, Wagner DD. Platelets roll on stimulated endothelium in vivo: an interaction mediated by endothelial P-selectin. Proc Natl Acad Sci U S A. 1995;92:7450-4.

[62] Massberg S, Enders G, Leiderer R, Eisenmenger S, Vestweber D, Krombach F, et al. Platelet-endothelial cell interactions during ischemia/reperfusion: the role of $\mathrm{P}$ selectin. Blood. 1998;92:507-15.

[63] Andre P, Denis CV, Ware J, Saffaripour S, Hynes RO, Ruggeri ZM, et al. Platelets adhere to and translocate on von Willebrand factor presented by endothelium in stimulated veins. Blood. 2000;96:3322-8.

[64] Bombeli T, Schwartz BR, Harlan JM. Adhesion of activated platelets to endothelial cells: evidence for a GPIIbIIIa-dependent bridging mechanism and novel roles for endothelial intercellular adhesion molecule 1 (ICAM-1), alphavbeta3 integrin, and GPIbalpha. J Exp Med. 1998;187:329-39.

[65] Defilippi P, Silengo L, Tarone G. Regulation of adhesion receptors expression in endothelial cells. Curr Top Microbiol Immunol. 1993;184:87-98.

[66] Gawaz M, Neumann FJ, Dickfeld T, Reininger A, Adelsberger H, Gebhardt A, et al. Vitronectin receptor (alpha(v)beta3) mediates platelet adhesion to the luminal aspect of endothelial cells: implications for reperfusion in acute myocardial infarction. Circulation. 1997;96:1809-18.

[67] Springer TA. Traffic signals for lymphocyte recirculation and leukocyte emigration: the multistep paradigm. Cell. 1994;76:301-14.

[68] Wagner DD, Burger PC. Platelets in inflammation and thrombosis. Arterioscler Thromb Vasc Biol. 2003;23:2131-7.

[69] [69] Gear AR, Camerini D. Platelet chemokines and chemokine receptors: linking hemostasis, inflammation, and host defense. Microcirculation. 2003;10:335-50.

[70] Klinger MH. Platelets and inflammation. Anat Embryol (Berl). 1997;196:1-11.

[71] Pinedo HM, Verheul HM, D'Amato RJ, Folkman J. Involvement of platelets in tumour angiogenesis? Lancet. 1998;352:1775-7.

[72] Brill A, Dashevsky O, Rivo J, Gozal Y, Varon D. Platelet-derived microparticles induce angiogenesis and stimulate post-ischemic revascularization. Cardiovasc Res. 2005;67:30-8.

[73] Carmeliet P. Angiogenesis in health and disease. Nat Med. 2003;9:653-60.

[74] Folkman J. Angiogenesis: an organizing principle for drug discovery? Nat Rev Drug Discov. 2007;6:273-86.

[75] Folkman J, Browder T, Palmblad J. Angiogenesis research: guidelines for translation to clinical application. Thromb Haemost. 2001;86:23-33.

[76] Jain RK. Molecular regulation of vessel maturation. Nat Med. 2003;9:685-93.

[77] Kisucka J, Butterfield CE, Duda DG, Eichenberger SC, Saffaripour S, Ware J, et al. Platelets and platelet adhesion support angiogenesis while preventing excessive hemorrhage. Proc Natl Acad Sci U S A. 2006;103:855-60. 
[78] Mehrad B, Keane MP, Strieter RM. Chemokines as mediators of angiogenesis. Thromb Haemost. 2007;97:755-62.

[79] Browder T, Folkman J, Pirie-Shepherd S. The hemostatic system as a regulator of angiogenesis. J Biol Chem. 2000;275:1521-4.

[80] Verheul HM, Jorna AS, Hoekman K, Broxterman HJ, Gebbink MF, Pinedo HM. Vascular endothelial growth factor-stimulated endothelial cells promote adhesion and activation of platelets. Blood. 2000;96:4216-21.

[81] Carmeliet P, Jain RK. Angiogenesis in cancer and other diseases. Nature. 2000;407:249-57.

[82] Armulik A, Abramsson A, Betsholtz C. Endothelial/pericyte interactions. Circ Res. 2005;97:512-23.

[83] Hanahan D, Folkman J. Patterns and emerging mechanisms of the angiogenic switch during tumorigenesis. Cell. 1996;86:353-64.

[84] Carmeliet P. VEGF gene therapy: stimulating angiogenesis or angioma-genesis? Nat Med. 2000;6:1102-3.

[85] Italiano JE, Jr., Richardson JL, Patel-Hett S, Battinelli E, Zaslavsky A, Short S, et al. Angiogenesis is regulated by a novel mechanism: pro- and antiangiogenic proteins are organized into separate platelet alpha granules and differentially released. Blood. 2008;111:1227-33.

[86] Burnstock G. Autonomic neurotransmission: 60 years since sir Henry Dale. Annu Rev Pharmacol Toxicol. 2009;49:1-30.

[87] Storkebaum E, Carmeliet P. Paracrine control of vascular innervation in health and disease. Acta Physiol (Oxf). 2011, Jun 20

[88] Feletou M, Kohler R, Vanhoutte PM. Endothelium-derived vasoactive factors and hypertension: possible roles in pathogenesis and as treatment targets. Curr Hypertens Rep. 2010;12:267-75.

[89] Luscher TF, Boulanger CM, Dohi Y, Yang ZH. Endothelium-derived contracting factors. Hypertension. 1992;19:117-30.

[90] Vanhoutte PM. Endothelial control of vasomotor function: from health to coronary disease. Circ J. 2003;67:572-5.

[91] Vanhoutte PM, Houston DS. Platelets, endothelium, and vasospasm. Circulation. 1985;72:728-34.

[92] Serhan CN, Savill J. Resolution of inflammation: the beginning programs the end. Nat Immunol. 2005;6:1191-7.

[93] Tomasek JJ, Gabbiani G, Hinz B, Chaponnier C, Brown RA. Myofibroblasts and mechano-regulation of connective tissue remodelling. Nat Rev Mol Cell Biol. 2002;3:349-63.

[94] Karasek MA. Does transformation of microvascular endothelial cells into myofibroblasts play a key role in the etiology and pathology of fibrotic disease? Med Hypotheses. 2007;68:650-5.

[95] Keeley EC, Mehrad B, Strieter RM. Fibrocytes: bringing new insights into mechanisms of inflammation and fibrosis. Int J Biochem Cell Biol. 2010;42:535-42.

[96] Keeley EC, Mehrad B, Strieter RM. The role of circulating mesenchymal progenitor cells (fibrocytes) in the pathogenesis of fibrotic disorders. Thromb Haemost. 2009;101:613-8.

[97] Nakamura M, Tokura Y. Epithelial-mesenchymal transition in the skin. J Dermatol Sci. 2011;61:7-13. 
[98] Opalenik SR, Davidson JM. Fibroblast differentiation of bone marrow-derived cells during wound repair. FASEB J. 2005;19:1561-3.

[99] Quan TE, Cowper SE, Bucala R. The role of circulating fibrocytes in fibrosis. Curr Rheumatol Rep. 2006;8:145-50.

[100] Desmouliere A, Geinoz A, Gabbiani F, Gabbiani G. Transforming growth factor-beta 1 induces alpha-smooth muscle actin expression in granulation tissue myofibroblasts and in quiescent and growing cultured fibroblasts. J Cell Biol. 1993;122:103-11.

[101] Kalluri R, Weinberg RA. The basics of epithelial-mesenchymal transition. J Clin Invest. 2009;119:1420-8.

[102] Krieg T, Abraham D, Lafyatis R. Fibrosis in connective tissue disease: the role of the myofibroblast and fibroblast-epithelial cell interactions. Arthritis Res Ther. 2007;9 Suppl 2:S4.

[103] Aden N, Nuttall A, Shiwen X, de Winter P, Leask A, Black CM, et al. Epithelial cells promote fibroblast activation via IL-1alpha in systemic sclerosis. J Invest Dermatol. 2010;130:2191-200.

[104] Friedlander M. Fibrosis and diseases of the eye. J Clin Invest. 2007;117:576-86.

[105] Strieter RM, Gomperts BN, Keane MP. The role of CXC chemokines in pulmonary fibrosis. J Clin Invest. 2007;117:549-56.

[106] Wynn TA. Common and unique mechanisms regulate fibrosis in various fibroproliferative diseases. J Clin Invest. 2007;117:524-9.

[107] Iredale JP. Models of liver fibrosis: exploring the dynamic nature of inflammation and repair in a solid organ. J Clin Invest. 2007;117:539-48.

[108] Anitua E, Andia I, Ardanza B, Nurden P, Nurden AT. Autologous platelets as a source of proteins for healing and tissue regeneration. Thromb Haemost. 2004;91:4-15.

[109] Villeneuve J, Block A, Le Bousse-Kerdiles MC, Lepreux S, Nurden P, Ripoche J, et al. Tissue inhibitors of matrix metalloproteinases in platelets and megakaryocytes: a novel organization for these secreted proteins. Exp Hematol. 2009;37:849-56.

[110] Nurden AT. Platelets and tissue remodeling: extending the role of the blood clotting system. Endocrinology. 2007;148:3053-5.

[111] Postlethwaite AE, Chiang TM. Platelet contributions to the pathogenesis of systemic sclerosis. Curr Opin Rheumatol. 2007;19:574-9.

[112] Katoh N. Platelets as versatile regulators of cutaneous inflammation. J Dermatol Sci. 2009;53:89-95.

[113] Andrae J, Gallini R, Betsholtz C. Role of platelet-derived growth factors in physiology and medicine. Genes Dev. 2008;22:1276-312.

[114] Blann AD, Lip GY, Beevers DG, McCollum CN. Soluble P-selectin in atherosclerosis: a comparison with endothelial cell and platelet markers. Thromb Haemost. 1997;77:1077-80.

[115] Fijnheer R, Frijns CJ, Korteweg J, Rommes H, Peters JH, Sixma JJ, et al. The origin of Pselectin as a circulating plasma protein. Thromb Haemost. 1997;77:1081-5.

[116] Viallard JF, Solanilla A, Gauthier B, Contin C, Dechanet J, Grosset C, et al. Increased soluble and platelet-associated CD40 ligand in essential thrombocythemia and reactive thrombocytosis. Blood. 2002;99:2612-4.

[117] Schonbeck U, Libby P. The CD40/CD154 receptor/ligand dyad. Cell Mol Life Sci. 2001;58:4-43. 
[118] Yanaba K, Takehara K, Sato S. Serum concentrations of soluble P-selectin glycoprotein ligand-1 are increased in patients with systemic sclerosis: association with lower frequency of pulmonary fibrosis. Ann Rheum Dis. 2004;63:583-7.

[119] Frenette PS, Denis CV, Weiss L, Jurk K, Subbarao S, Kehrel B, et al. P-Selectin glycoprotein ligand 1 (PSGL-1) is expressed on platelets and can mediate plateletendothelial interactions in vivo. J Exp Med. 2000;191:1413-22.

[120] Kasper B, Petersen F. Molecular pathways of platelet factor 4/CXCL4 signaling. Eur J Cell Biol. 2011;90:521-6.

[121] Marasini B, Cugno M, Bassani C, Stanzani M, Bottasso B, Agostoni A. Tissue-type plasminogen activator and von Willebrand factor plasma levels as markers of endothelial involvement in patients with Raynaud's phenomenon. Int J Microcirc Clin Exp. 1992;11:375-82.

[122] Solanilla A, Villeneuve J, Auguste P, Hugues M, Alioum A, Lepreux S, et al. The transport of high amounts of vascular endothelial growth factor by blood platelets underlines their potential contribution in systemic sclerosis angiogenesis. Rheumatology (Oxford). 2009;48:1036-44.

[123] Riddle JM, Bluhm GB, Pitchford WC, McElroy H, Jimenea C, Leisen J, et al. A comparative study of platelet reactivity in arthritis. Ann N Y Acad Sci. 1981;370:22-9.

[124] Maeda M, Kachi H, Mori S. Ultrastructural observation of platelets from patients with progressive systemic sclerosis (PSS). J Dermatol. 1998;25:222-30.

[125] Kahaleh MB, Osborn I, Leroy EC. Elevated levels of circulating platelet aggregates and beta-thromboglobulin in scleroderma. Ann Intern Med. 1982;96:610-3.

[126] Cuenca R, Fernandez-Cortijo J, Lima J, Fonollosa V, Simeon CP, Pico M, et al. [Platelet function study in primary Raynaud's phenomenon and Raynaud's phenomenon associated with scleroderma]. Med Clin (Barc). 1990;95:761-3.

[127] Kallenberg CG, Vellenga E, Wouda AA, The TH. Platelet activation, fibrinolytic activity and circulating immune complexes in Raynaud's phenomenon. J Rheumatol. 1982;9:878-84.

[128] Pamuk GE, Turgut B, Pamuk ON, Vural O, Demir M, Cakir N. Increased circulating platelet-leucocyte complexes in patients with primary Raynaud's phenomenon and Raynaud's phenomenon secondary to systemic sclerosis: a comparative study. Blood Coagul Fibrinolysis. 2007;18:297-302.

[129] Lee P, Norman CS, Sukenik S, Alderdice CA. The clinical significance of coagulation abnormalities in systemic sclerosis (scleroderma). J Rheumatol. 1985;12:514-7.

[130] Seibold JR, Harris JN. Plasma beta-thromboglobulin in the differential diagnosis of Raynaud's phenomenon. J Rheumatol. 1985;12:99-103.

[131] Lima J, Fonollosa V, Fernandez-Cortijo J, Ordi J, Cuenca R, Khamashta MA, et al. Platelet activation, endothelial cell dysfunction in the absence of anticardiolipin antibodies in systemic sclerosis. J Rheumatol. 1991;18:1833-6.

[132] Silveri F, De Angelis R, Poggi A, Muti S, Bonapace G, Argentati F, et al. Relative roles of endothelial cell damage and platelet activation in primary Raynaud's phenomenon (RP) and RP secondary to systemic sclerosis. Scand J Rheumatol. 2001;30:290-6.

[133] Macko RF, Gelber AC, Young BA, Lowitt MH, White B, Wigley FM, et al. Increased circulating concentrations of the counteradhesive proteins SPARC and 
thrombospondin-1 in systemic sclerosis (scleroderma). Relationship to platelet and endothelial cell activation. J Rheumatol. 2002;29:2565-70.

[134] Maeda M, Kachi H, Mori S. Plasma levels of molecular markers of blood coagulation and fibrinolysis in progressive systemic sclerosis (PSS). J Dermatol Sci. 1996;11:223-7.

[135] Klimiuk PS, Grennan A, Weinkove C, Jayson MI. Platelet serotonin in systemic sclerosis. Ann Rheum Dis. 1989;48:586-9.

[136] Biondi ML, Marasini B, Bianchi E, Agostoni A. Plasma free and intraplatelet serotonin in patients with Raynaud's phenomenon. Int J Cardiol. 1988;19:335-9.

[137] Reilly IA, Roy L, Fitzgerald GA. Biosynthesis of thromboxane in patients with systemic sclerosis and Raynaud's phenomenon. Br Med J (Clin Res Ed). 1986;292:1037-9.

[138] Wilkinson D, Vowden P, Gilks L, Latif AB, Rajah SM, Kester RC. Plasma eicosanoids, platelet function and cold sensitivity. Br J Surg. 1989;76:401-5.

[139] Herrick AL, Illingworth K, Blann A, Hay CR, Hollis S, Jayson MI. Von Willebrand factor, thrombomodulin, thromboxane, beta-thromboglobulin and markers of fibrinolysis in primary Raynaud's phenomenon and systemic sclerosis. Ann Rheum Dis. 1996;55:122-7.

[140] Blann AD, Constans J, Carpentier P, Renard M, Satger B, Guerin V, et al. Soluble P selectin in systemic sclerosis: relationship with von Willebrand factor, autoantibodies and diffuse or localised/limited disease. Thromb Res. 2003;109:203-6.

[141] Allanore Y, Borderie D, Meune C, Lemarechal H, Weber S, Ekindjian OG, et al. Increased plasma soluble CD40 ligand concentrations in systemic sclerosis and association with pulmonary arterial hypertension and digital ulcers. Ann Rheum Dis. 2005;64:481-3.

[142] Komura K, Sato S, Hasegawa M, Fujimoto M, Takehara K. Elevated circulating CD40L concentrations in patients with systemic sclerosis. J Rheumatol. 2004;31:514-9.

[143] Guiducci S, Distler JH, Jungel A, Huscher D, Huber LC, Michel BA, et al. The relationship between plasma microparticles and disease manifestations in patients with systemic sclerosis. Arthritis Rheum. 2008;58:2845-53.

[144] Lau CS, McLaren M, Mackay I, Belch JJ. Baseline plasma fibrinolysis and its correlation with clinical manifestations in patients with Raynaud's phenomenon. Ann Rheum Dis. 1993;52:443-8.

[145] Frayha RA, Shulman LE, Stevens MB. Hematological abnormalities in scleroderma. A study of 180 cases. Acta Haematol. 1980;64:25-30.

[146] Valentini G, Chianese U, Tirri G, Giordano M. [Thrombocytosis in progressive generalized sclerosis (scleroderma) and in other rheumatic diseases]. $Z$ Rheumatol. 1978;37:233-41.

[147] Smyth SS, Monroe DM, 3rd, Wysokinski WE, McBane RD, 2nd, Whiteheart SW, Becker $\mathrm{RC}$, et al. Platelet activation and its patient-specific consequences. Thromb Res. 2008;122:435-41.

[148] Yee DL, Sun CW, Bergeron AL, Dong JF, Bray PF. Aggregometry detects platelet hyperreactivity in healthy individuals. Blood. 2005;106:2723-9.

[149] Chatterjee MS, Purvis JE, Brass LF, Diamond SL. Pairwise agonist scanning predicts cellular signaling responses to combinatorial stimuli. Nat Biotechnol. 2010;28:727-32.

[150] Huang EM, Detwiler TC. Characteristics of the synergistic actions of platelet agonists. Blood. 1981;57:685-91. 
[151] Packham MA, Guccione MA, Chang PL, Mustard JF. Platelet aggregation and release: effects of low concentrations of thrombin or collagen. Am J Physiol. 1973;225:38-47.

[152] Ware JA, Smith M, Salzman EW. Synergism of platelet-aggregating agents. Role of elevation of cytoplasmic calcium. J Clin Invest. 1987;80:267-71.

[153] Chiang TM, Takayama H, Postlethwaite AE. Increase in platelet non-integrin type I collagen receptor in patients with systemic sclerosis. Thromb Res. 2006;117:299-306.

[154] Friedhoff LT, Seibold JR, Kim HC, Simester KS. Serotonin induced platelet aggregation in systemic sclerosis. Clin Exp Rheumatol. 1984;2:119-23.

[155] Goodfield MJ, Orchard MA, Rowell NR. Increased platelet sensitivity to collageninduced aggregation in whole blood patients with systemic sclerosis. Clin Exp Rheumatol. 1988;6:285-8.

[156] Biondi ML, Marasini B. Abnormal platelet aggregation in patients with Raynaud's phenomenon. J Clin Pathol. 1989;42:716-8.

[157] Goodfield MJ, Orchard MA, Rowell NR. Whole blood platelet aggregation and coagulation factors in patients with systemic sclerosis. Br J Haematol. 1993;84:675-80.

[158] Lau CS, McLaren M, Saniabadi A, Belch JJ. Increased whole blood platelet aggregation in patients with Raynaud's phenomenon with or without systemic sclerosis. Scand J Rheumatol. 1993;22:97-101.

[159] Kahaleh MB, Scharstein KK, LeRoy EC. Enhanced platelet adhesion to collagen in scleroderma. Effect of scleroderma plasma and scleroderma platelets. J Rheumatol. $1985 ; 12: 468-71$.

[160] Belch JJ, O'Dowd A, Forbes CD, Sturrock RD. Platelet sensitivity to a prostacyclin analogue in systemic sclerosis. Br J Rheumatol. 1985;24:346-50.

[161] Price JE, Klimiuk PS, Jayson MI. In vitro platelet aggregability studies: lack of evidence for platelet hyperactivity in systemic sclerosis. Ann Rheum Dis. 1991;50:567-71.

[162] Cook-Mills JM, Marchese ME, Abdala-Valencia H. Vascular Cell Adhesion Molecule-1 Expression and Signaling During Disease: Regulation by Reactive Oxygen Species and Antioxidants. Antioxid Redox Signal. 2011 May 11

[163] Pober JS. Endothelial activation: intracellular signaling pathways. Arthritis Res. 2002;4 Suppl 3:S109-16.

[164] Sellak H, Franzini E, Hakim J, Pasquier C. Reactive oxygen species rapidly increase endothelial ICAM-1 ability to bind neutrophils without detectable upregulation. Blood. 1994;83:2669-77.

[165] Takano M, Meneshian A, Sheikh E, Yamakawa Y, Wilkins KB, Hopkins EA, et al. Rapid upregulation of endothelial $\mathrm{P}$-selectin expression via reactive oxygen species generation. Am J Physiol Heart Circ Physiol. 2002;283:H2054-61.

[166] Faller DV. Endothelial cell responses to hypoxic stress. Clin Exp Pharmacol Physiol. 1999;26:74-84.

[167] Michiels C, Arnould T, Remacle J. Endothelial cell responses to hypoxia: initiation of a cascade of cellular interactions. Biochim Biophys Acta. 2000;1497:1-10.

[168] Yamakawa M, Liu LX, Date T, Belanger AJ, Vincent KA, Akita GY, et al. Hypoxiainducible factor-1 mediates activation of cultured vascular endothelial cells by inducing multiple angiogenic factors. Circ Res. 2003;93:664-73.

[169] Beyer C, Schett G, Gay S, Distler O, Distler JH. Hypoxia. Hypoxia in the pathogenesis of systemic sclerosis. Arthritis Res Ther. 2009;11:220. 
[170] Distler O, Distler JH, Scheid A, Acker T, Hirth A, Rethage J, et al. Uncontrolled expression of vascular endothelial growth factor and its receptors leads to insufficient skin angiogenesis in patients with systemic sclerosis. Circ Res. 2004;95:109-16.

[171] Hunzelmann N, Krieg T. Scleroderma: from pathophysiology to novel therapeutic approaches. Exp Dermatol. 2010;19:393-400.

[172] Silverstein JL, Steen VD, Medsger TA, Jr., Falanga V. Cutaneous hypoxia in patients with systemic sclerosis (scleroderma). Arch Dermatol. 1988;124:1379-82.

[173] Bradford A. The role of hypoxia and platelets in air travel-related venous thromboembolism. Curr Pharm Des. 2007;13:2668-72.

[174] Bradley TD, Floras JS. Obstructive sleep apnoea and its cardiovascular consequences. Lancet. 2009;373:82-93.

[175] Bombeli T, Schwartz BR, Harlan JM. Endothelial cells undergoing apoptosis become proadhesive for nonactivated platelets. Blood. 1999;93:3831-8.

[176] Sindram D, Porte RJ, Hoffman MR, Bentley RC, Clavien PA. Platelets induce sinusoidal endothelial cell apoptosis upon reperfusion of the cold ischemic rat liver. Gastroenterology. 2000;118:183-91.

[177] Fleming JN, Schwartz SM. The pathology of scleroderma vascular disease. Rheum Dis Clin North Am. 2008;34:41-55; vi.

[178] Guiducci S, Distler O, Distler JH, Matucci-Cerinic M. Mechanisms of vascular damage in SSc--implications for vascular treatment strategies. Rheumatology (Oxford). 2008;47 Suppl 5:v18-20.

[179] Kahaleh B. The microvascular endothelium in scleroderma. Rheumatology (Oxford). 2008;47 Suppl 5:v14-5.

[180] Muller-Ladner U, Distler O, Ibba-Manneschi L, Neumann E, Gay S. Mechanisms of vascular damage in systemic sclerosis. Autoimmunity. 2009;42:587-95.

[181] Greaves M, Malia RG, Milford Ward A, Moult J, Holt CM, Lindsey N, et al. Elevated von Willebrand factor antigen in systemic sclerosis: relationship to visceral disease. Br J Rheumatol. 1988;27:281-5.

[182] Kahaleh MB, Osborn I, LeRoy EC. Increased factor VIII/von Willebrand factor antigen and von Willebrand factor activity in scleroderma and in Raynaud's phenomenon. Ann Intern Med. 1981;94:482-4.

[183] Mannucci PM, Lombardi R, Lattuada A, Perticucci E, Valsecchi R, Remuzzi G. Supranormal von Willebrand factor multimers in scleroderma. Blood. 1989;73:158691.

[184] Cuenca R, Fernadez-Cortijo J, Fonollosa V, Lima J, Simeon CP, Vilardell M, et al. von Willebrand factor activity in primary and in scleroderma-associated Raynaud's phenomenon. Lancet. 1990;335:1095.

[185] Kahaleh MB. Endothelin, an endothelial-dependent vasoconstrictor in scleroderma. Enhanced production and profibrotic action. Arthritis Rheum. 1991;34:978-83.

[186] Gruschwitz MS, Hornstein OP, von Den Driesch P. Correlation of soluble adhesion molecules in the peripheral blood of scleroderma patients with their in situ expression and with disease activity. Arthritis Rheum. 1995;38:184-9.

[187] Mercie P, Seigneur M, Conri C. Plasma thrombomodulin as a marker of vascular damage in systemic sclerosis. J Rheumatol. 1995;22:1440-1. 
[188] Andersen GN, Caidahl K, Kazzam E, Petersson AS, Waldenstrom A, MinchevaNilsson L, et al. Correlation between increased nitric oxide production and markers of endothelial activation in systemic sclerosis: findings with the soluble adhesion molecules E-selectin, intercellular adhesion molecule 1, and vascular cell adhesion molecule 1. Arthritis Rheum. 2000;43:1085-93.

[189] van Gils JM, Zwaginga JJ, Hordijk PL. Molecular and functional interactions among monocytes, platelets, and endothelial cells and their relevance for cardiovascular diseases. J Leukoc Biol. 2009;85:195-204.

[190] Yamamoto T, Katayama I, Nishioka K. Nitric oxide production and inducible nitric oxide synthase expression in systemic sclerosis. J Rheumatol. 1998;25:314-7.

[191] Del Papa N, Colombo G, Fracchiolla N, Moronetti LM, Ingegnoli F, Maglione W, et al. Circulating endothelial cells as a marker of ongoing vascular disease in systemic sclerosis. Arthritis Rheum. 2004;50:1296-304.

[192] Jun JB, Kuechle M, Harlan JM, Elkon KB. Fibroblast and endothelial apoptosis in systemic sclerosis. Curr Opin Rheumatol. 2003;15:756-60.

[193] Hummers LK. Biomarkers of vascular disease in scleroderma. Rheumatology (Oxford). 2008;47 Suppl 5:v21-2.

[194] Flavahan NA, Flavahan S, Mitra S, Chotani MA. The vasculopathy of Raynaud's phenomenon and scleroderma. Rheum Dis Clin North Am. 2003;29:275-91, vi.

[195] Fonseca C, Abraham D, Ponticos M. Neuronal regulators and vascular dysfunction in Raynaud's phenomenon and systemic sclerosis. Curr Vasc Pharmacol. 2009;7:34-9.

[196] Generini S, Matucci Cerinic M. Raynaud's phenomenon and vascular disease in systemic sclerosis. Adv Exp Med Biol. 1999;455:93-100.

[197] Kahaleh MB. Raynaud's phenomenon and the vascular disease in scleroderma. Curr Opin Rheumatol. 1995;7:529-34.

[198] Sunderkotter C, Riemekasten G. Pathophysiology and clinical consequences of Raynaud's phenomenon related to systemic sclerosis. Rheumatology (Oxford). 2006;45 Suppl 3:iii33-5.

[199] Bukhari M, Herrick AL, Moore T, Manning J, Jayson MI. Increased nailfold capillary dimensions in primary Raynaud's phenomenon and systemic sclerosis. $\mathrm{Br} \mathrm{J}$ Rheumatol. 1996;35:1127-31.

[200] Herrick AL. Pathogenesis of Raynaud's phenomenon. Rheumatology (Oxford). 2005;44:587-96.

[201] Polidoro L, Barnabei R, Giorgini P, Petrazzi L, Ferri C, Properzi G. Platelet activation in patients with the Raynaud's Phenomenon. Intern Med J. 2010 Dec 1

[202] Turton EP, Kent PJ, Kester RC. The aetiology of Raynaud's phenomenon. Cardiovasc Surg. 1998;6:431-40.

[203] Czirjak L, Molnar I, Csipo I, Szabolcs M, Mihaly A, Szegedi G. Anti-platelet antibodies against gpIIb/IIIa in systemic sclerosis. Clin Exp Rheumatol. 1994;12:527-9.

[204] Weyrich AS, Lindemann S, Zimmerman GA. The evolving role of platelets in inflammation. J Thromb Haemost. 2003;1:1897-905.

[205] Dor Y, Djonov V, Abramovitch R, Itin A, Fishman GI, Carmeliet P, et al. Conditional switching of VEGF provides new insights into adult neovascularization and proangiogenic therapy. EMBO J. 2002;21:1939-47.

[206] Lee RJ, Springer ML, Blanco-Bose WE, Shaw R, Ursell PC, Blau HM. VEGF gene delivery to myocardium: deleterious effects of unregulated expression. Circulation. 2000;102:898-901. 
[207] Springer ML, Chen AS, Kraft PE, Bednarski M, Blau HM. VEGF gene delivery to muscle: potential role for vasculogenesis in adults. Mol Cell. 1998;2:549-58.

[208] Distler JH, Strapatsas T, Huscher D, Dees C, Akhmetshina A, Kiener HP, et al. Dysbalance of angiogenic and angiostatic mediators in patients with mixed connective tissue disease. Ann Rheum Dis. 2011;70:1197-202.

[209] Trojanowska M. Cellular and molecular aspects of vascular dysfunction in systemic sclerosis. Nat Rev Rheumatol. 2010;6:453-60.

[210] Kissin EY, Merkel PA, Lafyatis R. Myofibroblasts and hyalinized collagen as markers of skin disease in systemic sclerosis. Arthritis Rheum. 2006;54:3655-60.

[211] Zaldivar MM, Pauels K, von Hundelshausen P, Berres ML, Schmitz P, Bornemann J, et al. CXC chemokine ligand $4(\mathrm{Cxcl} 4)$ is a platelet-derived mediator of experimental liver fibrosis. Hepatology. 2010;51:1345-53.

[212] Dees C, Akhmetshina A, Zerr P, Reich N, Palumbo K, Horn A, et al. Platelet-derived serotonin links vascular disease and tissue fibrosis. J Exp Med. 2011;208:961-72.

[213] Artlett CM. Animal models of scleroderma: fresh insights. Curr Opin Rheumatol. 2010;22:677-82.

[214] Beyer C, Schett G, Distler O, Distler JH. Animal models of systemic sclerosis: prospects and limitations. Arthritis Rheum. 2010;62:2831-44. 


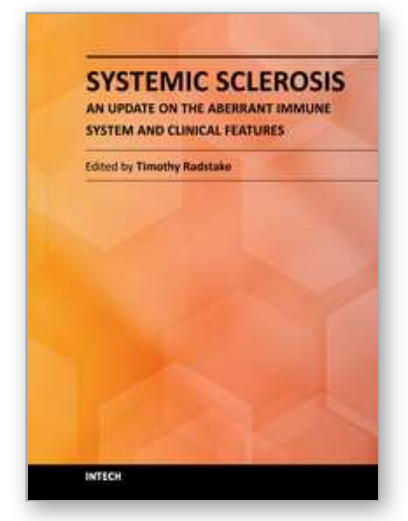

\section{Systemic Sclerosis - An Update on the Aberrant Immune System and Clinical Features}

Edited by Dr Timothy Radstake

ISBN 978-953-307-869-4

Hard cover, 206 pages

Publisher InTech

Published online 03, February, 2012

Published in print edition February, 2012

Systemic sclerosis (SSc), or often referred to as Scleroderma (tight skin), is characterized by an exaggerated formation of collagen fibers in the skin, which leads to fibrosis. Accumulating evidence now points toward three pathological hallmarks that are implicated in Ssc, the order of which has yet to be determined: endothelial dysfunction, autoantibody formation, and activation of fibroblasts. This current book provides up-to-date information on the pathogenesis and clinical features of this severe syndrome. It is our hope that this book will aid both clinicians and researchers in dealing with patients with this clinical syndrome. In addition, we hope to shed more light on this rare and severely disabling syndrome, ultimately leading to better research and successful therapeutic targeting.

\section{How to reference}

In order to correctly reference this scholarly work, feel free to copy and paste the following:

Sébastien Lepreux, Anne Solanilla, Julien Villeneuve, Joël Constans, Alexis Desmoulière and Jean Ripoche (2012). Blood Platelets and Systemic Sclerosis, Systemic Sclerosis - An Update on the Aberrant Immune System and Clinical Features, Dr Timothy Radstake (Ed.), ISBN: 978-953-307-869-4, InTech, Available from: http://www.intechopen.com/books/systemic-sclerosis-an-update-on-the-aberrant-immune-system-and-clinicalfeatures/blood-platelets-and-systemic-sclerosis

\section{INTECH}

open science | open minds

\author{
InTech Europe \\ University Campus STeP Ri \\ Slavka Krautzeka 83/A \\ 51000 Rijeka, Croatia \\ Phone: +385 (51) 770447 \\ Fax: +385 (51) 686166 \\ www.intechopen.com
}

\author{
InTech China \\ Unit 405, Office Block, Hotel Equatorial Shanghai \\ No.65, Yan An Road (West), Shanghai, 200040, China \\ 中国上海市延安西路65号上海国际贵都大饭店办公楼 405 单元 \\ Phone: +86-21-62489820 \\ Fax: +86-21-62489821
}


(C) 2012 The Author(s). Licensee IntechOpen. This is an open access article distributed under the terms of the Creative Commons Attribution 3.0 License, which permits unrestricted use, distribution, and reproduction in any medium, provided the original work is properly cited. 